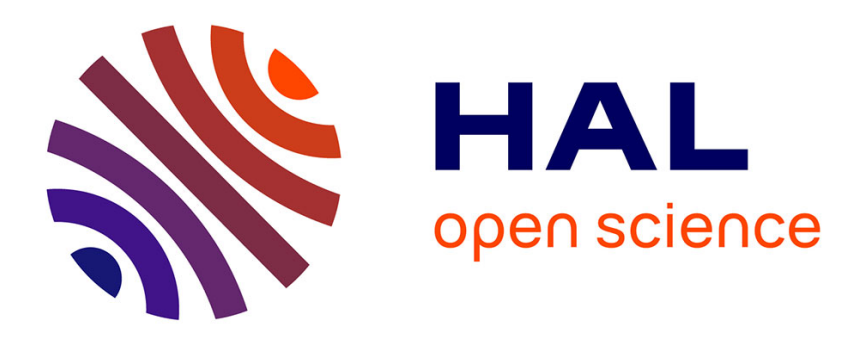

\title{
Sources of dietary cadmium to the Pacific oyster
}

\author{
J.C. Christie, L.I. Bendell
}

\section{To cite this version:}

J.C. Christie, L.I. Bendell. Sources of dietary cadmium to the Pacific oyster. Marine Environmental

Research, 2009, 68 (3), pp.97. 10.1016/j.marenvres.2009.04.008 . hal-00563077

\section{HAL Id: hal-00563077 \\ https://hal.science/hal-00563077}

Submitted on 4 Feb 2011

HAL is a multi-disciplinary open access archive for the deposit and dissemination of scientific research documents, whether they are published or not. The documents may come from teaching and research institutions in France or abroad, or from public or private research centers.
L'archive ouverte pluridisciplinaire HAL, est destinée au dépôt et à la diffusion de documents scientifiques de niveau recherche, publiés ou non, émanant des établissements d'enseignement et de recherche français ou étrangers, des laboratoires publics ou privés. 


\section{Accepted Manuscript}

Sources of dietary cadmium to the Pacific oyster Crassostrea gigas

J.C. Christie, L.I. Bendell

PII:

S0141-1136(09)00042-7

DOI:

10.1016/j.marenvres.2009.04.008

Reference:

MERE 3335

To appear in:

Marine Environmental Research

Received Date:

9 July 2008

Revised Date:

18 April 2009

Accepted Date:

20 April 2009

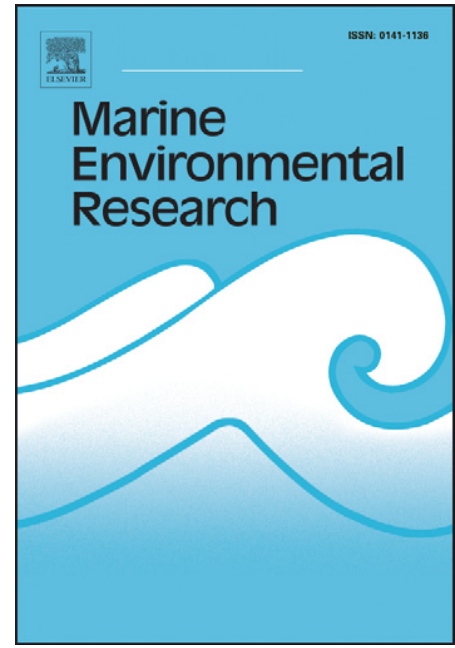

Please cite this article as: Christie, J.C., Bendell, L.I., Sources of dietary cadmium to the Pacific oyster Crassostrea gigas, Marine Environmental Research (2009), doi: 10.1016/j.marenvres.2009.04.008

This is a PDF file of an unedited manuscript that has been accepted for publication. As a service to our customers we are providing this early version of the manuscript. The manuscript will undergo copyediting, typesetting, and review of the resulting proof before it is published in its final form. Please note that during the production process errors may be discovered which could affect the content, and all legal disclaimers that apply to the journal pertain. 


\section{5 *corresponding author; bendell@sfu.ca}

\title{
Sources of dietary cadmium to the Pacific oyster Crassostrea gigas
}

\author{
J.C. Christie and L.I. Bendell *
}

\section{Department of Biological Sciences, Simon Fraser University, Burnaby B.C. V5A 1S6}

Tel: $\mathbf{7 7 8 7 8 2 5 6 2 1 ~ F a x : ~} \mathbf{7 7 8 7 8 2 3 4 9 6}$

1.0 ABSTRACT. Oysters from the Pacific north-west coast contain high cadmium

concentrations (greater than $13.5 \mu \mathrm{g} \mathrm{g}^{-1}$ dry weight), which exceed consumer guidelines for international markets. Oysters are selective filter-feeders and attempts which have focused on suspended particulate matter (SPM) as a means to assess the importance of diet as a route of cadmium exposure have met with limited success. Here we use actual gut contents as an alternate to SPM to assess if this is a better predictor of cadmium exposure to the oyster via the diet. We also applied stable isotope analysis, $\delta^{13} \mathrm{C}$ and $\delta^{15} \mathrm{~N}$, to determine the origin of organic material (from terrestrial to oceanic) ingested by the oyster. Oyster gut and tissue cadmium concentrations and corresponding isotopic signatures were determined every two-three months for 22 months from 10 locations on the west coast of B.C. Gut and tissue cadmium concentrations were correlated $\left(r^{2}=0.40 ; p<0.05\right)$, suggesting that diet could account for at least $40 \%$ of observed cadmium oysters residues. Oyster gut and tissue cadmium concentrations and $\delta^{13} \mathrm{C}$ and $\delta^{15} \mathrm{~N}$ signatures were region dependent. Oysters from the most marine influenced sites contained gut and tissue cadmium residues of $30.4 \pm 3.08$ (S.E.) $\mu \mathrm{g} \mathrm{g}^{-1}$ and $6.0 \pm 0.6 \mu \mathrm{g} \mathrm{g}^{-1}$, respectively, and a stable isotopic signature typical of marine phytoplankton. In contrast, oysters sampled from regions influenced by coastal processes contained significantly greater concentrations of cadmium, $43.0 \pm 2.4 \mu \mathrm{g} \mathrm{g}^{-1}$ and $10.2 \pm 0.68 \mu \mathrm{g} \mathrm{g}^{-1}$ gut and tissue respectively with isotopic signatures representative of terrestrial organic matter. This indicates that diet is an important 
24 source of cadmium to oysters from the Pacific north-west, however its importance is region

25 dependent and cannot be simply ascribed to one source of organic matter alone.

26 Key Words: Oysters, cadmium, diet, organic matter, stable isotopes 


\section{$28 \quad 2.0$ INTRODUCTION}

29 The ever increasing global demand for protein coupled with the decline in wild fisheries

30 has resulted in countries such as Canada turning to aquaculture, both shellfish and finfish to meet

31 this demand. Since 1998, on the west coast of Canada, the aquaculture industry has undergone

32 aggressive expansion, in part to meet this global need, but also to gain from the economies of

33 such industry. For the B.C shellfish industry aggressive expansion was planned for the farming

34 of Manila clams (Venerupis philippinarum) and oysters ( Crassostrea gigas) (Kruzynski 2004).

35 Hence, the rejection of three shipments of B.C. oysters from the Hong Kong market, due to high

36 cadmium levels, a toxic metal, in excess of $2 \mu \mathrm{g} \mathrm{g}^{-1}$ wet weight was seen as a major setback to

37 what was being forecasted as an important economic driver for the industry (Kruzynski et al.

$382002,2004)$.

The outcome of this rejection that is, the potential loss of international markets, triggered

40 a number of research initiatives to address the source of this cadmium to B.C. oysters (Kruzynski

41 et al. 2002, 2004, Rasmussen et al. 2007, Lekhi et al. 2008, Widmeyer and Bendell-Young

42 2008). Further motivation came from Health Canada who issued oyster consumption guidelines

43 of $460 \mathrm{~g}$ and $60 \mathrm{~g}$ per month for adults and children respectively (Canadian Food Inspection

44 Agency 2003). More recent assessments of Cheng and Gobas (2007) and Widmeyer and

45 Bendell-Young (2008), have indicated that these guidelines need to be much more stringent,

46 especially for target populations such as First Nations.

47 The two main routes of cadmium exposure to the oysters and to bivalves in general are

48 diet and direct uptake from the water column via the gill and mouth, as dissolved cadmium. Both

49 have the potential to contribute with the relative importance of each source dependent on a 
50 number of abiotic (e.g., water chemistry) and biotic (e.g., selective filter-feeding by the bivalve)

51 factors. The importance of diet however, has only been clearly demonstrated under controlled

52 laboratory conditions, (e.g., Ettajani et al. 2001, Reinfelder et al. 1997). Demonstrating diet as a

53 route of exposure under field conditions is much more difficult. The most common approach for

54 determining dietary exposure under field conditions is through filtering suspended particulate

55 matter (SPM) from the water column, as a surrogate for what the oyster is filtering from the

56 water column (e.g.,Widmeyer and Bendell-Young 2008 and Lekhi et al. 2008). However, oysters

57 are selective filter-feeders (Navarro and Thompson 1995, Cognie et al. 2001, Bayne 2002), and

58 what is removed as SPM is not necessarily what the oyster has filtered from the water column as

59 diet. Widmeyer and Bendell-Young 2008 concluded that suspended and deposited sediments

60 were not good predictors of oyster cadmium concentrations. Similarly, Lekhi et al. 2008,

61 concluded that cadmium concentrations of SPM filtered from the water column (three size

62 fractions of $0.4-3,3.0-20$ and $>20 \mu \mathrm{m}$ ), were poor predictors of tissue cadmium concentrations in

63 cultured oysters. Indeed, there is yet a way to selectively remove from the seawater, exactly

64 what the oyster has filtered from the water column.

65 It still remains then to assess the role of diet, that is, what the oyster has actually filtered

66 from the water column and ingested, as a source of cadmium to the oyster. Given their highly

67 selective feeding behavior, rather than measure suspended particulate matter (SPM)

68 concentrations within the associated water column as an indicator of oyster diet, we chose to

69 measure cadmium concentrations and the corresponding stable isotope signature of the actual gut

70 contents that is, exactly what the oyster had filtered from the water column. Based on estimates

71 from the literature on gut retention times, it is likely what we are measuring is that what the 
72 oyster has filtered within the last 8-10 hours (Chaparro et al. 2001) and truly represents "dietary"

73 exposure.

74 Stable carbon and nitrogen isotope ratios have become valuable tools for ecologists trying

75 to define trophic levels and understand feeding relationships in aquatic communities (Fry and

76 Sherr 1984, Kwak and Zedler 1997, Peterson et al. 1985, Riera et al. 1999). The differential

77 fractionation of heavy $\left({ }^{13} \mathrm{C}\right.$ and $\left.{ }^{15} \mathrm{~N}\right)$ and light $\left({ }^{12} \mathrm{C}\right.$ and $\left.{ }^{14} \mathrm{~N}\right)$ carbon and nitrogen isotopes during

78 food assimilation results in consumers exhibiting $\delta^{13} \mathrm{C}$ and $\delta^{15} \mathrm{~N}$ signatures that are enriched

79 over those of their food source (DeNiro and Epstein 1978, 1981). Further, as the $\delta^{13} \mathrm{C}$ signatures

80 of organic matter will reflect the carbon source from which they are derived, tracing different

81 organic sources through feeding consumers is possible (Stephenson and Lyon 1982). The

82 nitrogen stable isotope signature $\left(\delta^{15} \mathrm{~N}\right)$ exhibits a relatively predictable enrichment of $\approx 3.5 \%$

83 through successive trophic levels (Minagawa and Wada 1984) whereas the enrichment factor for

$84 \delta^{13} \mathrm{C}$ is less consistent (0 to $1.5 \%$ ) (Fry and Sherr 1984). Photoautotroph $\delta^{13} \mathrm{C}$ signatures will

85 vary depending on the type of carbon fixation (i.e. $\mathrm{C}_{3}$ vs $\mathrm{C}_{4} \mathrm{vs} \mathrm{CAM}$ ) and the inorganic carbon

86 sources available (i.e. $\mathrm{CO}_{2}$ and $\left.\mathrm{HCO}_{3}^{-}\right)$. Riverine phytoplankton $(\sim-35 \%$ ), estuarine

87 phytoplankton $\left(\sim-24 \%\right.$ ) and (terrestrial vegetation $\left(\sim-28 \%\right.$ ) have comparatively light $\delta^{13} \mathrm{C}$

88 signatures (Riera and Richard 1997). Oceanic phytoplankton generally have $\delta^{13} \mathrm{C}$ signatures

89 between $-20 \%$ to $-22 \%$, while benthic diatoms have relatively heavy signatures of $-14 \%$ o to -16

$90 \%$ (Riera and Richard 1997). Given these distinct signatures, here we apply stable isotope

91 analysis to determine the origins of organic matter ingested by the oyster to aid in elucidating

92 sources of cadmium to these bivalves. 
Our objectives are therefore two-fold. First we determine cadmium concentrations in the

94 gut (i.e., actual diet) and tissues of oysters, from 10 sites from coastal B.C., sampled every two-

95 three months over a two year period to determine both the spatial and temporal variability in diet

96 and tissue cadmium concentrations and to assess if gut cadmium does correlate to tissue

97 cadmium concentrations. Second, we apply stable isotope analysis of the gut and tissue to

98 determine the source of diet and thereby the source of cadmium via the diet to the oyster.

\section{$99 \quad 3.0$ METHODS}

100 3.1 Study Sites. All sampling sites were located along the southern coast of British Columbia,

101 Canada, within two regions; Barkley Sound an open coastal embayment on the southwest coast

102 of Vancouver Island and Desolation Sound a large Marine Park along the west coast of the

103 mainland at the uppermost north end the Strait of Georgia (Figure 1a and 1b). Four sites were

104 located within Barkley Sound; (1) Effingham Inlet, (2) Seddall Island, located in Useless Inlet,

105 (3) Fatty Basin, a shallow, bowl-shaped, elongated depression, and, (4) Poett Nook, a small,

106 highly protected cove (Figure 1a). The area has a significant freshwater supply via Poett Creek

107 (personal observation). For Fatty Basin, connection to Barkley Sound is via two narrow

108 passages, the "large gut" via Useless Inlet and the "small gut" via Rainy Basin. The constrictive

109 nature of the two connecting passages strongly influences the oceanographic characteristics of

110 the basin.

111 Within the larger region of Desolation Sound six study sites were chosen; (1) Trevenen

112 Bay situated on the east side of Malaspina Peninsula at the south end of Malaspina Inlet, (2)

113 Thor's Cove within Lancelot Inlet 4 km east of Trevenen Bay separated by Gifford Peninsula,

114 (3) Gorge Harbor a highly protected site, due to its single narrow opening into the Strait of 
115 Georgia, on the west side of Cortes Island, (4) Teakerne Arm located at the end of the $7 \mathrm{~km}$

116 inlet, which of the region had the most significant freshwater input via a permanent waterfall,

117 (5) Orchard Bay, located within Waddington Channel on the southwest side of West Redonda

118 Island and, (6) Redonda Bay, situated at the northwest tip of West Redonda Island (Figure 1b).

119 All sites are regions where active shellfish farming is occurring.

120

121 3.2 Water Chemistry. Depth profiles of chlorophyll- $a$, salinity, temperature and turbidity were

122 measured at each site coincident with oyster sampling using a multi-parameter probe (YSI 6600

123 multi-parameter sonde). Complete profiles were taken from the air-surface/water interface to

124 approximately 30 meters depth. For regression analysis, 3-5 values from 5-7 meters depth were

125 averaged (S.E. were $<1 \%$ for averaged values) to represent water chemistry characteristics for

126 each site.

127 3.3 Sample analysis, tissue and gut. Crassostrea gigas juveniles of the same age and genetic

128 stock were distributed to all sites in July 2001. The juveniles were grown on clean shells of con-

129 specifics attached to two-strand polypropylene strings hung in the water column, a common

130 aquaculture technique termed "string or long-line culture". For the purposes of this study, 3-10

131 oysters from 5-7 meters depth, were collected from each of the sites at a minimum bimonthly

132 basis beginning in October 2002 until August 2004. Samples were cleaned of epibonts by hand

133 and transferred on ice to the laboratory to be frozen. They were later partially thawed, shucked

134 and dissected into two components: (1) gut contents exclusive of digestive membrane and (2)

135 remaining tissue (herein referred to as "tissue"). For subsequent cadmium analysis, both gut and

136 tissue were dried to a constant weight at $60^{\circ} \mathrm{C}$ and homogenized into a fine powder using mortar

137 and pestle. 
138 3.4 Stable Isotope Analysis. One mg sub-samples of gut and tissue were placed in 9x5 mm tin

139 capsules for CF-IRMS analysis. The University of California Stable Isotope Facility conducted

140 the analysis using a Europa 20/20 stable isotope analyzer. All isotopic data are given in the

141 customary delta notation in units of parts per thousand (\%o) relative to the standards Pee Dee

142 Belemnite (PDB) for ${ }^{13} \mathrm{C}$ and atmospheric nitrogen for ${ }^{15} \mathrm{~N}$. Standard deviations for ${ }^{13} \mathrm{C}$ and ${ }^{15} \mathrm{~N}$

143 were $\pm 0.03 \%$ and $\pm 0.06 \%$ respectively, for standards analyzed along with the samples.

144 Analytical precision ( \pm 1 S.D.) based on triplicate analyses performed on some samples

145 established good analytical reproducibility $\left( \pm 0.1 \%\right.$ and $\pm 0.2 \%$ for ${ }^{13} \mathrm{C}$ and $\left.{ }^{15} \mathrm{~N}\right)$ where

$$
{ }^{13} \mathrm{C}_{\text {sample }} \text { or }{ }^{15} \mathrm{~N}_{\text {sample }}=\left[\left(\mathrm{R}_{\text {sample }} / \mathrm{R}_{\text {standard }}\right)-1\right] \times 1000
$$

$$
\text { and } \mathrm{R}={ }^{13} \mathrm{C} /{ }^{12} \mathrm{C} \text { or }{ }^{15} \mathrm{~N} /{ }^{14} \mathrm{~N}
$$

148 3.5 Trace Metal analysis. Sub-samples (gut and tissue) of $150 \mathrm{mg}$ were digested with

149 environmental grade nitric acid in $25 \mathrm{ml}$ acid washed Erlenmeyer flasks. Samples were digested

150 until all organics were converted to $\mathrm{CO}_{2}$ and then boiled to dryness $(0.5 \mathrm{ml})$. The remaining

151 liquid was diluted with $10 \mathrm{ml}$ de-ionized water and analyzed for cadmium with a Perkin Elmer

152 model 100 Atomic Absorption Spectrophotometer. Procedural blanks and reference material

153 (NIST 1566b Oyster Tissue) were run with the samples as individual samples. The standard

154 deviation of the analyzed reference material was $\pm 0.2 \mu \mathrm{g} \mathrm{g}^{-1}$ with accuracy for all samples within

$15510 \%$ of the certified values $(2.48 \pm 0.08$ S.E. $)$. All cadmium concentrations are expressed as $\mu \mathrm{g}$

$156 \mathrm{~g}^{-1}$ dry weight of sample (gut or tissue).

157 3.6 Statistical Analysis. All statistical analyses were done using JMP v4.03. Initial tests for data 158 normality (normality probability plots) indicated some deviations from normality with data 
159 demonstrating some degree of negative skewness, however, not enough to warrant data

160 transformation for the use of non-parametric tests which tend to be less robust.

161 Relationships between water chemistry parameters (Chlorophyll $a$, temperature, turbidity

162 and salinity) and oyster tissue cadmium concentrations were assessed with simple linear

163 regressions. Linear regressions were also used to analyze the relationship between gut and tissue

164 cadmium concentrations. A simple student's t-test was used to test for significant differences in

165 the overall grand mean cadmium gut and tissue concentrations between the two regions. A

166 multiple comparison ANOVA (Tukey-Kramer) was used to determine significant differences in

167 cadmium concentrations among sampling periods within each site. A Tukey-Kramer was chosen

168 because of the unequal number of samples available to test at each site over the course of the

169 sampling. Dual isotope plots with 95\% confidence intervals were used to assess differences in

$170 \quad \delta^{13} \mathrm{C}$ and $\delta^{15} \mathrm{~N}$ signatures between sites during sampling periods. Linear regressions were used to

171 analyze the relationship between $\delta^{13} \mathrm{C}$ in tissue and gut as well as relationships between gut and

172 tissue cadmium concentrations and $\delta^{13} \mathrm{C}$ signatures. The level for significance for all tests was $\mathrm{p}$

$173<0.05$

174

$175 \quad$ 4.0 RESULTS

176 4.1 Correlations between water chemistry parameters and oyster tissue cadmium

177 concentrations. Of the 4 factors measured (temperature, chlorophyll $a$, salinity, turbidity),

178 oyster cadmium tissue concentrations were only weakly dependent on temperature $\left(r^{2}=-0.22 ; p<\right.$

179 0.05) (Figure 2). 
4.2 Cadmium concentrations in gut versus tissue. Although the oyster is highly selective in

181 its feeding, particles can be selected for based on size alone, rather than quality. This is especially true during periods of low particle concentrations (Navarro and Thompson 1995). To ensure that poor quality gut components were not contributing to amounts of cadmium measured in the gut (that is, gut cadmium levels could be related to gut inorganic content rather than associated with organic content), on a subsample of oysters, we determined the relationship between amounts of cadmium measured in the gut with gut inorganic content. Inorganic content was determined by igniting the gut contents at $450^{\circ} \mathrm{C}$ for 4 hours and weighing the remaining residue. Gut inorganic content ranged from $4-12 \%$, with no relationship between $\%$ inorganic content and gut cadmium concentration (Figure 3). Cadmium gut concentrations were shown to be significant positive predictors of cadmium tissue levels accounting for close to $40 \%$ of observed tissue cadmium concentrations $\left(r^{2}=0.4 ; p<0.05\right.$; Figure 4$)$.

4.3 Oyster cadmium concentrations; between region and within site comparisons. Average cadmium concentrations for tissue and gut, for each site and the two regions during the sampling periods are presented in Figures 5a, for gut and $5 \mathrm{~b}$ for tissue. Standard errors have been omitted for figure clarity however, are presented in Figure 4. Overall oysters sampled from Desolation Sound contained greater amounts of gut and tissue cadmium levels $\left(43.0 \pm 2.4\right.$ (S.E.) $\mu \mathrm{g} \mathrm{g}^{-1}$ and $10.2 \pm 0.68 \mu \mathrm{g} \mathrm{g}^{-1}$ respectively) 197 than their Barkley Sound counterparts (of 30.4 $\pm 3.08 \mu \mathrm{g} \mathrm{g}^{-1}$ and $6.0 \pm 0.6 \mu \mathrm{g} \mathrm{g}^{-1}$, respectively) (students ttest; $\mathrm{p}<0.05$.). Maximum gut cadmium concentrations of $80.4 \mu \mathrm{g} \mathrm{g}^{-1}$ were determined for oysters sampled from Effingham Inlet in Barkley Sound during January 2004 (Tukey-Kramer; p < 0.05) (Figure 5a). Within Desolation Sound the significantly highest gut content concentration was $91.9 \mu \mathrm{g} \mathrm{g}^{-1}$ in

201 oysters sampled from Orchard Bay during May 2003 (Tukey-Kramer; $\mathrm{p}<0.05$ ) (Figure 5a). The greatest

202 tissue cadmium concentrations determined for oysters sampled from Barkley Sound, were again found for 203 those oysters sampled from Effingham Inlet, April $2003\left(16.1 \mu \mathrm{g} \mathrm{g}^{-1}\right.$; Tukey-Kramer; $\mathrm{p}<0.05$; Figure 
204 5b). For Desolation Sound, maximum oyster tissue cadmium concentrations of $26.1 \mu \mathrm{g} \mathrm{g}^{-1}$ (Tukey-

205 Kramer; $\mathrm{p}<0.05$ ) were again from oysters sampled from Orchard Bay in August of 2004 (Figure 5b).

206 4.4 Stable isotope analysis. Dual isotope plots for gut and tissue at each site for all sampling

207 periods are presented by region in Figure 6a for Barkley Sound and 6b for Desolation Sound.

208 The most striking difference between the two regions with respect to the stable isotopic

209 signatures of oyster gut and tissue were the difference in ranges for primarily $\delta^{13} \mathrm{C}$. Oyster gut

210 and tissue from Barkley Sound contained a smaller range of mean carbon isotopic signatures

211 (-21 to -19, Figure 6a) as compared to Desolation Sound where signatures had a much greater

212 range in values (-25 to -19 Figure $6 \mathrm{~b}$ ). Those sites located within Barkley Sound displayed

213 heavier $\delta^{15} \mathrm{~N}$ values (7-11, Figure 6a) as compared to Desolation Sound sites which had lighter

$214 \delta^{15} \mathrm{~N}$ values (6-9, Figure $\left.6 \mathrm{~b}\right)$. Overall both isotopes indicated a distinction in diet between the

215 two regions.

2164.5 Using $\delta^{13} \mathrm{C}$ isotopic signatures to assess sources of diet and hence cadmium to B.C.

217 oysters. All sampling dates were pooled and average cadmium levels and $\delta^{13} \mathrm{C}$ signatures for

218 both oyster components were calculated for each site and relationships between the carbon

219 isotope signature and cadmium levels for gut and tissue determined. The relationship between

220 the isotopic signatures for gut and tissue was also determined. $\delta^{13} \mathrm{C}$ in tissue and gut was highly

221 correlated (Figure $\left.7 ; \mathrm{r}^{2}=0.93 ; \mathrm{p}<0.05\right)$ indicating the role of $\delta^{13} \mathrm{C}$ signatures of organic matter

222 tracing different organic sources through consumers. A significant negative relationship was

223 found between both gut and tissue cadmium and $\delta^{13} \mathrm{C}$, (Figures 8a and 8b; $\mathrm{r}^{2}=0.67$ and 0.4

224 respectively; $\mathrm{p}<0.05$ ). Oysters sampled from sites located in Desolation Sound with higher

225 cadmium concentrations had depleted $\delta^{13} \mathrm{C}$ signatures indicative of more terrestrial sources as 
226 compared to samples from Barkley Sound, a region more influenced by marine sources of

227 organic matter as indicated by the $\delta^{13} \mathrm{C}$ (Riera and Richard 1997). 
5.0 DISCUSSION

\subsection{The importance of diet as a source of cadmium to B.C. oysters.}

Cadmium concentrations determined for oyster gut contents were correlated with cadmium tissue levels $\left(\mathrm{r}^{2}=0.4, \mathrm{p}<0.05\right)$ suggesting that diet was an important contributor to oyster tissue cadmium concentrations. The importance of dietary uptake as a source of cadmium to filter-feeding bivalves has been demonstrated under laboratory conditions for a number of bivalves, including mussels (e.g., Arifin and Bendell-Young 2000), oysters and clams

237 (e.g., Ettajani et al. 1992, Reinfelder et al. 1997), supporting our findings here. components enriched with cadmium due to the presence of cadmium rich metallothioneins. For our study, removal of gut contents was done ensuring that none of the digestive membrane was

241 included. Thus, measured cadmium gut concentrations could be attributed to just what the oyster

242 had ingested with this gut cadmium accounting for $40 \%$ of the variation in oyster cadmium tissue

243 residues. It is likely the remaining variation in oyster tissue cadmium residues (exclusive of gut

244 contents) can be attributed to uptake of cadmium by the oyster in its dissolved form, either

245 through the mouth or gill (e.g., Roesjadi and Robinson 1994, Lekhi et al 2008). What is most

246 difficult to determine under field conditions however, is the relative importance of diet versus

247 dissolved cadmium to determined cadmium residues. This is dependent on a complex interplay

248 of both abiotic (e.g., salinity and temperature) and biotic factors (e.g., filter-feeding rate and diet 
249 selection) and will vary dependent on which factor is more important at a particular time or in a

250 particular region.

251

For example, we found that oyster tissue cadmium residues were inversely related to

252 temperature, possibly indicative of a slight seasonality effect on determined tissue cadmium.

253 Lekhi et al. (2008) also noted a temperature affect on tissue cadmium levels, where for one

254 location on the west coast of B.C., cadmium levels in oysters tissue sampled monthly over a

255 period of a year were greatest during periods of lower temperature, i.e., winter, as compared to

256 summer. It remains unclear why oysters would tend to have greater cadmium tissue residues

257 during the colder winter months as compared to the warmer seasons. One possibility suggested

258 by Lekhi et al. (2008) is during winter months, when filter-feeding is less, there is a net weight

259 loss in tissue mass which would lead to an apparent increase in cadmium residues. Recently

260 Bendell and Feng (2009) however, indicated that seasonal increases in oyster tissue cadmium

261 could not be readily ascribed to changes in oyster mass alone.

2635.2 Use of stable isotopes to determine the source of diet to the filter-feeding oyster.

Kaehler et al. (2000) through stable isotope analysis was able to demonstrate that

265 although phytoplankton (oceanic derived particulate organic matter POM) was an important

266 dietary component for both zooplankton and benthos, kelp-derived organic matter accounted for

$267>30 \%$ of the nearshore animal's diet. Kang et al. (1999) also using stable isotopes were able to

268 identify food sources of the suspension feeding cockle (Cerastoderma edule). These authors

269 reported two major food sources that were age and season dependent. Bouillon et al. (2000) also

270 successfully used stable isotope analysis to determine sources of suspended organic matter to

271 zooplankton in an estuarine mangrove. These authors were able to determine that despite large 
272 amounts of terrestrial and mangrove detritus present in the water column, the locally produced

273 phytoplankton were more important carbon sources for the zooplankton. Riera et al. (1999) used

274 stable isotope analysis to provide a quantification of the relative importance of organic matter of

275 different origins to suspension feeding bivalves. Surveys of bivalves along estuarine gradients

276 have pointed to a trend of increasing incorporation of terrestrially derived detritus into the diet

277 near upper reaches of the estuary (Incze et al. 1982, Stephenson and Lyon 1982, Riera and

278 Richard 1996, 1997). Recently Hill et al. (2006) determined biogeographic and near-shore off-

279 shore trends in isotopic ratios of intertidal mussels and their food sources, both macroalgae and

280 SPM around the coast of southern Africa. These authors noted, for mussels, as we found for

281 oysters in this study, distinct geographic variation in tissue carbon signatures. However, tissue

282 trends were not readily related to carbon values of SPM, again demonstrating that SPM filtered

283 from the water column likely does not represent what the filter-feeding bivalve is actually

284 selecting and hence ingesting as diet. Interestingly, Hill et al. (2006) noted that SPM exhibited

285 trends of $\delta^{13} \mathrm{C}$ depletion from near shore to offshore, suggesting a shift from a signature

286 influenced by macroalgae to one more representative of oceanic phytoplankton.

287 5.2.1 Barkley Sound: Within the region two significant site patterns were found. Effingham

288 Inlet across all sampling time periods appeared to exhibit a diet comprised entirely of oceanic

289 marine phytoplankton $\left(-20 \delta^{13} \mathrm{C}, 7.60 \delta^{15} \mathrm{~N}\right)$ (Riera and Richard 1997). Given the sampling

290 sites location, the mouth of the inlet, and the considerable influence Imperial Eagle Channel has

291 on the food sources available at this site, this would be expected. Contrasting this was the

292 heavier $\delta^{13} \mathrm{C}$ and $\delta^{15} \mathrm{~N}$ signatures found within oysters sampled from for Fatty Basin $\left(-19.7 \delta^{13} \mathrm{C}\right.$,

$2938.39 \delta^{15} \mathrm{~N}$ ) possibly due the influence of benthic microalgae in their diet. Because of differences

294 in the carbon and nitrogen pools available to them, benthic microalgae are readily 
295 distinguishable (in terms of $\delta^{15} \mathrm{~N}$ and $\delta^{13} \mathrm{C}$ signatures) than terrestrial vascular plants and

296 phytoplankton (Kang et al. 1999). Unlike the other three sites within Barkley Sound, Fatty

297 Basin is a shallow elongated depression readily mixed through wind and tidally action (Baillie

298 and Welsh 1980; De Jonge and van Beusekom 1992). This mixing would result in the

299 suspension of benthic microalgae making it available to filter feeders. Mixing would also allow

300 for recently deposited particulate organic matter that has been degraded by consumers and

301 isotopically enriched, to be resuspended and made available again as a food source to the

302 oysters. Both processes would result in heavier $\delta^{15} \mathrm{~N}$ values as observed here.

303 5.2.2 Desolation Sound: In general across all the sampling periods the sites Teakerne Arm,

304 Orchard Bay and Redonda Bay contained carbon signatures $\left(\delta^{13} \mathrm{C}\right.$ of $-22.9,-23.0$ and -22.4

305 respectively) that indicated that the diet of oysters from these locations contained more terrestrial

306 organic matter as a food source as compared to oysters sampled from Barkley Sound $\left(\delta^{13} \mathrm{C}\right.$ range

307 of -19.48 to -20.1) (Riera and Richard 1997). Orchard Bay oysters appear to have had the most

308 significant portion of their diet derived from upland origins i.e., the most depleted of the carbon

309 signatures. Oysters sampled from Gorge Harbor however, showed no terrestrial dietary influence

310 with signatures indicative of marine sources of organic matter $\left(\delta^{13} \mathrm{C}\right.$ of -20.16$)$. It should be

311 noted that Gorge Harbor likely receives the most significant input from the Strait of Georgia, in

312 terms of oceanic derived organic matter, and it is likely that their diet is consistently based on

313 these inputs.

314 6.0 Conclusions Based on the $\delta^{13} \mathrm{C}$ and $\delta^{15} \mathrm{~N}$ analysis and determined tissue and gut cadmium

315 concentrations, two main conclusions can be drawn; 1) gut contents correlated with cadmium

316 residues found in oysters and 2) the type of organic matter (terrestrial or oceanic) being filtered

317 and ingested by the oyster is region and site dependent, hence diet can contribute greater or 
318 lesser amounts of cadmium to the filter-feeding oysters depending on region and the site within

319 the region. In Effingham Inlet, where both diet and tissue concentrations of cadmium in oysters

320 were the greatest, oyster diet was comprised almost exclusively of marine phytoplankton. This

321 was in contrast with oysters sampled from within the same region but at different sites which had

322 much lower cadmium tissue and gut concentrations with diets appearing to be more mixed with

323 other sources of marine organic matter (e.g., marine diatoms). Oysters sampled from regions that

324 were less directly influenced by oceanic processes had gut carbon signatures characteristic of

325 terrestrial organic matter, with corresponding high cadmium concentrations in both the gut and

326 tissue.

327 Our findings suggest that the type of organic matter (terrestrial or oceanic) and amounts

328 of cadmium associated with the organic matter on which the oyster is feeding, is region and site

329 dependent. This then makes it difficult to predict where the oyster will be at greatest exposure

330 via the diet to elevated cadmium levels, unless one goes specifically to the site of interest and

331 measures dietary exposure directly at that site. Importantly, by measuring what the oyster had

332 ingested, rather than SPM, we were able to demonstrate the importance of diet as a source of

333 cadmium to the oyster, a route of exposure that would have been missed if SPM collected from

334 the water column had been used as an indicator of dietary exposure alone. 


\section{$337 \quad 7.0$ Acknowledgements.}

338

339 The authors gratefully acknowledge Dr. G. Kruzynski and Dr. W. Heath for the collection of

340 oyster samples used in this study. The authors are grateful to P. Farrokhyar for providing the

341 data on the relationship between oyster gut cadmium concentrations and gut \% inorganic content.

342 Two anonymous reviewers greatly improved the original manuscript. Funding for this study was

343 provided by an NSERC discovery grant to L.B. 


\section{$346 \quad$ 8.0 References Cited.}

347 Bendell, L.I. ,C. Feng. 2009. Spatial and temporal variations in cadmium concentrations and 348 burdens in the Pacific Oyster (Crassostrea gigas) sampled from the Pacific North-West. Marine 349 Pollution Bulletin. in press.

350 Arifin, Z., Bendell-Young, L.I., 2000. Influence of a selective feeding strategy by the blue

351 mussel on the assimilation of ${ }^{109} \mathrm{Cd}$ from environmentally relevant seston matrices. Marine

352 Ecology Progress Series 192, 181-193.

353 Baillie, P.W., Welsh, B.L., 1980. The effect of tidal resuspension on the distribution of intertidal

354 epipelic algae in an estuary. Estuarine Coastal Marine Science 10, 165-180.

355 Bayne, B.L., 2002. A physiological comparison between Pacific oysters Crassostrea gigas and

356 Sydney Rock oysters Saccostrea glomerata: food, feeding and growth in a shared estuarine

357 habitat. Marine Ecology Progress Series 232, 163-178.

358 Bouillon,S., Mohan, P.C., Sreenivas, N., Dehairs, F., 2000. Sources of suspended organic matter 359 and selective feeding by zooplankton in an estuarine mangrove ecosystem, as traced by stable

360 isotopes. Marine Ecology Progress Series 208, 79-92.

361 Canadian Food Inspection Agency, 2003. Food safety facts on bivalve shellfish in British 362 Columbia. Canadian Food Inspection Agency Fact Sheet.

363 http://www.inspection.gc.ca.proxy.lib.sfu.ca/english/corpaffr/foodfacts/bivalvee.pdf 
365 Chaparro, O.R., Soto, C.J., Thompson, R.J., Concha, II., 2001. Feeding behavior during brooding

366 in the oyster Ostrea chilensis: gut retention time in adults and larvae and potential use of larval

367 faeces by adults. Marine Ecology Progress Series 222, 119-129.

368 Cheng, W.W., Gobas, F.A.P.C., 2007. Assessment of human health risks of consumption of

369 cadmium contaminated cultured oysters. Human and Ecological risk assessment. 13, 370-382.

370 Cognie, B., Barille, L., Rince, Y., 2001. Selective feeding on the oyster Crassostrea giga fed on

371 a natural microphytobenthos assemblage Estuaries 24, 126-134.

372 De Jonge, V.N., Van Beusekom, J.E.E., 1992. Contribution of resuspended microphytobenthos

373 to total phytoplankton in the Ems estuary and its possible role for grazers. Netherlands Journal of

374 Sea Research 30, 91-105.

375 DeNiro, M.J., Epstein, S., 1978. Influence of diet on the distribution of carbon isotopes in 376 animals. Geochimica et Cosmochimica Acta 42, 495-506.

377 DeNiro, M.J., Epstein, S., 1981. Influence of diet on the distribution of nitrogen isotopes in 378 animals. Geochimica et Cosmochimica Acta 45, 341-351.

379 Ettajani, H., Amiard-Triquet, C., Amiard, J.C., 1992. Etude expérimentale du transfert de deux 380 eléments traces $(\mathrm{Ag}, \mathrm{Cu})$ dans une chaîne trophique marine: Eau - particules (Sédiment Natural, 381 microalgue) - mollusques filtreurs (Crassostrea gigas Thunberg). Water Air Soil Pollution 65, $382 \quad 215-236$.

383 Ettajani, H., Berthet, B., Amiard, J.C., Chevolot L., 2001. Determination of cadmium 384 partitioning in microalgae and oysters: contribution to the assessment of trophic transfer. 385 Archives of Environmental Contamination and Toxicology 40, 209-221. 
386 Fry, B., Sherr, E.B., 1984., $\delta^{13} \mathrm{C}$ measurements as indicators of carbon flow in marine and 387 freshwater ecosystems. Contributions in Marine Science 27, 13-47.

388 Hill, J.M., McQuad, C.D., Kaehler, S., 2006. Biogeograpahic and nearshore-offshore trends in 389 isotope ratios of intertidal mussels and their food sourcs around the coast of southern Africa.

390 Marine Ecology Progress Series 318, 63-73.

391 Incze, L.S., Mayer, L.M., Sherr, E.B., Macko, S.A., 1982. Carbon inputs to bivalve mollusks: a 392 comparison of two estuaries. Canadian Journal of Fisheries and Aquatic Science 39, 1348-1352.

393 Kaehler, S., Pakhomov E.A., McQuaid C.D., 2000 : Trophic structure of the marine food web at 394 the Prince Edward Islands (Southern Ocean) determined by delta C-13 and delta N-15 analysis. 395 Marine Ecology Progress Series. 208, 13-20.

396 Kang, C.K., Sauriau, P.G., Richard, P., Blanchard, G.F., 1999. Food sources of the infaunal 397 suspension-feeding bivalve Cerastoderma edule in a muddy sandflat of Marennes-Oleron Bay, 398 as determined by analyses of carbon and nitrogen stable isotopes. Marine Ecology Progress 399 Series 187, 147-158.

400 Kruzynski, G., 2004. Cadmium in oysters and scallops: the BC experience. Toxicology Letters $401 \quad 148,159-169$.

402 Kruzynski, G.M., Addison, R.F., Macdonald, R.W., 2002. Possible pathways of cadmium into 403 the Pacific Oyster (Crassostrea gigas) as cultured on the coast of British Columbia, Institute of 404 Ocean Sciences, March 6-7, 2001. Canadian Technical Report of Fisheries and Aquatic Sciences $4052405, \mathrm{vi}+65 \mathrm{pp}$. 
406 Kwak, T.J., Zedler, J.B., 1997. Food web analysis of southern California coastal wetlands using

407 multiple stable isotopes. Oecologia 110, 262-277.

408 Lekhi, P., Cassis, D., Pearce, C.M., Ebell, N., Maldonado M.T., Orians, K.J., 2008. Role of

409 dissolved and particulate cadmium in the accumulation of cadmium in cultured oysters

410 (Crassostrea gigas). Science of the Total Environment 393, 309-325.

411 Minagawa, M., Wada, E., 1984. Stepwise enrichment of $\delta^{15} \mathrm{~N}$ along food chains: further

412 evidence and the relation between $\delta^{15} \mathrm{~N}$ and animal age. Geochimica et Cosmochimica Acta 48, $413 \quad 1135-1140$.

414 Navarro, J.M., Thompson, R.J., 1995. Seasonal fluctuations in the size spectra, biochemical 415 composition and nutritive value of the seston available to a suspension-feeding bivalve in a 416 subarctic environment. Marine Ecology Progress Series 125, 95-106.

417 Peterson, B.J., Howarth, R.W., Garritt, R.H., 1985. Multiple stable isotopes used to trace the 418 flow of organic matter in estuarine food webs. Science 227, 1361-1363.

419 Rasmussen, R., Morrissey, M.T., Cheney, D., 2007. Effect of age and tissue on the cadmium 420 concentration in Pacific oysters (Crassostrea gigas) Journal of Shellfish Research 26, 173-179.

421 Reinfelder, J.R., Wang, W.X., Luoma, S.N., Fisher, N.S., 1997. Assimilation efficiencies and

422 turnover rates of trace elements in marine bivalves: a comparison of oysters, clams and mussels. 423 Marine Biology 129, 443-452.

424 Riera, P., Richard, P., 1996. Isotopic determination of food sources of Crassostrea gigas along a 425 trophic gradient in the estuarine bay of Marennes-Oléron. Estuarine Coastal and Shelf Science $42642,347-360$. 
427 Riera, P., Richard P., 1997. Temporal variation of $\delta^{13} \mathrm{C}$ in particulate organic matter and oyster

428 Crassostrea gigas in Marennes-Oléron Bay (France): effect of freshwater inflow. Marine

429 Ecology Progress Series 147, 105-115.

430 Riera, P., Stal, L.J., Nieuwenhuize, J., Richard, P., Blanchard, G., Gentil, F., 1999.

431 Determination of food sources for benthic invertebrates in a salt marsh (Aiguillon Bay, France)

432 by carbon and nitrogen stable isotopes: importance of locally produced sources. Marine Ecology

433 Progress Series 187, 301-307.

434 Roesjadi, G., Klerks, P., 1989. A kinetic analysis of cadmium-binding to metallothionein and 435 other intracellular ligands in oyster gills Journal of Experimental Zoology 251, 1-12.

436 Roesjadi, G., Robinson, W.E. 1994. Metal regulation in aquatic animals: mechanisms of uptake, 437 accumulation and release. In D.C. Malins and G. Ostrander (Eds.) Molecular Mechanisms in 438 Aquatic Toxicology. Lewis Publishers, Boca Raton. 387-420.

439 Stephenson, R.L., Lyon, G.L., 1982. Carbon-13 depletion in an estuarine bivalve: detection of 440 marine and terrestrial food sources. Oecologia (Berlin) 55, 110-113.

441 Widmeyer, J.R., Bendell-Young, L.I., 2008. Heavy Metal Levels in Suspended Sediments, 442 Crassostrea gigas, and the Risk to Humans. Arch Environ Contam Toxicol. 55: 442-452. 


\section{List of Figures}

448 Figure 1. The location of and sampling locations within the two regions on the west coast of 449 B.C., Canada; A) Barkley Sound (scale 1:144,546; map:ground), B) Desolation Sound (scale 450 1:235,689; map:ground). 1. Effingham Inlet, 2. Seddall Island, 3. Fatty Basin, 4. Poett Nook,

451 5.Trevenen Bay, 6. Thor’s Cove, 7. Gorge Harbour, 8. Teakerne Arm, 9. Orchard Bay, 10.

452 Redonda Bay.

453 Figure 2. Average oyster tissue cadmium determined for all sites and sampling periods versus

454 water column temperature taken at 3-5 m depth. $\mathrm{r}^{2}=-0.22$ and is significant at $\mathrm{p}<0.05, \mathrm{~N}=68$ ).

455 Values are means of 3-10 oysters. Standard errors omitted for clarity but are presented in Figure 4564.

457 Figure 3. Cadmium in B.C. oyster gut in $\mu \mathrm{g} \mathrm{g}^{-1}$ dry weight versus gut $\%$ inorganic content. $\mathrm{N}=55$ 458 individual oysters.

459 Figure 4. Relationship between tissue and gut cadmium over all sampling periods for all 460 locations. Values are means of $3-10$ oysters \pm 1 S.E. $r^{2}=0.4 ; p<0.05$. are oysters from 461 Desolation Sound, are oysters from Barkley Sound. N=68.

462 Figure 5a and 5b. Average cadmium concentrations in gut and tissue for each site at for the two 463 regions. Date of sampling has been provided for seasonal comparisons. Values are means of 346410 oysters. Standard errors omitted for clarity but are presented in Figure 4.

465 Figure 6a and 6b. Dual isotope plots of average $\delta^{13} \mathrm{C}$ and $\delta^{15} \mathrm{~N}$ signatures for gut (solid) and 466 tissue (open) for oysters sampled from Barkley (a) and Desolation (b) Sounds during each 
467 sampling period over the two year study. Bi-directional error bars are $95 \%$ confidence intervals.

468 Values are means of 3-10 oysters.

469 Figure 7. Relationship between tissue and gut carbon signatures. are oysters from Desolation

470 Sound, are oysters from Barkley Sound, $\mathrm{r}^{2}=0.93 ; \mathrm{p}<0.05$. Values are averages over all

471 sampling times, \pm S.E. Samples sizes are provided in Figure 8.

472 Figure 8. Relationships between carbon signatures and cadmium gut (a) and tissue (b)

473 concentrations. Values are averages over all sampling periods for each site \pm S.E. Samples sizes

474 provided in figure legend. 


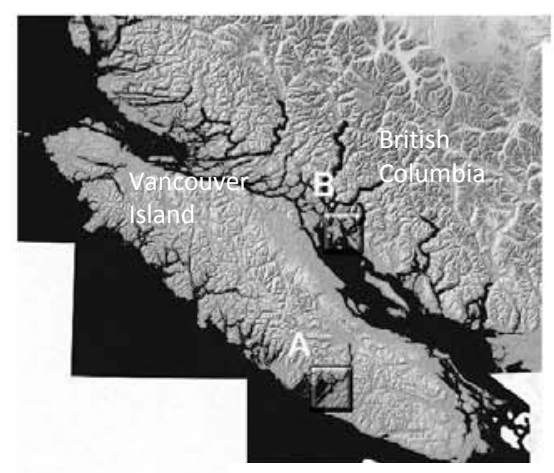

A

B
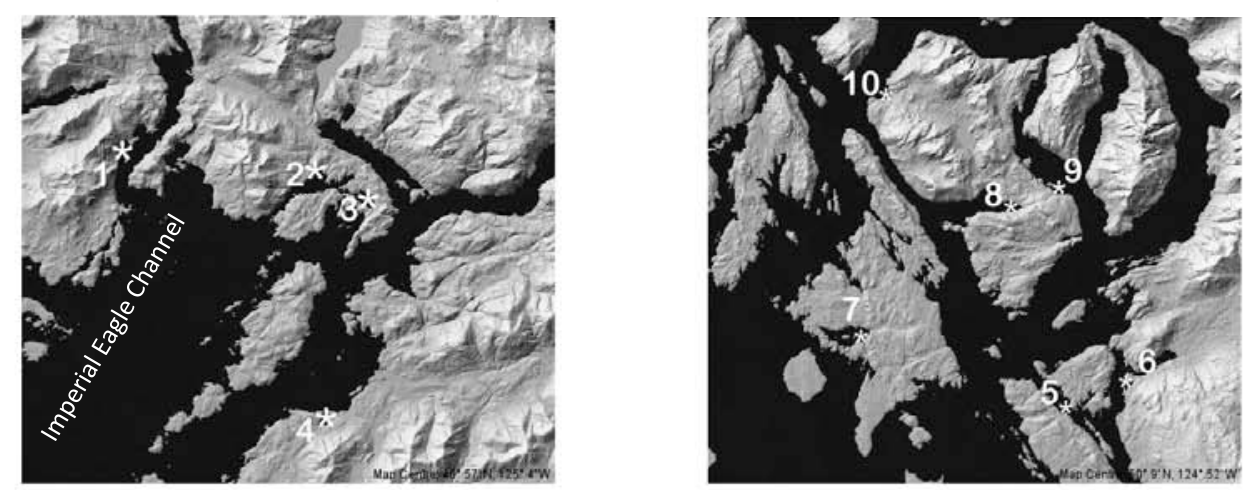

Figure 1 


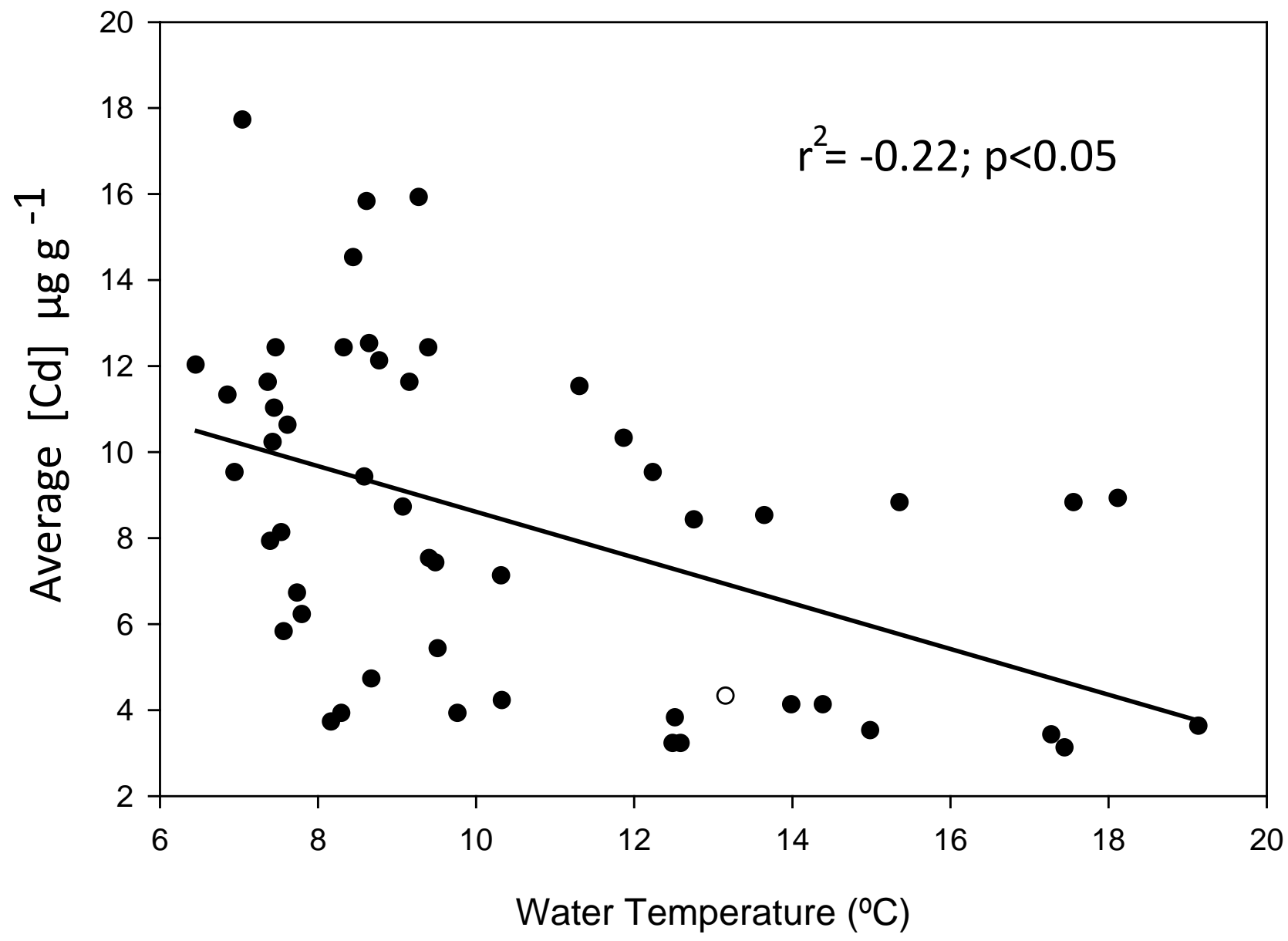

Figure 2 


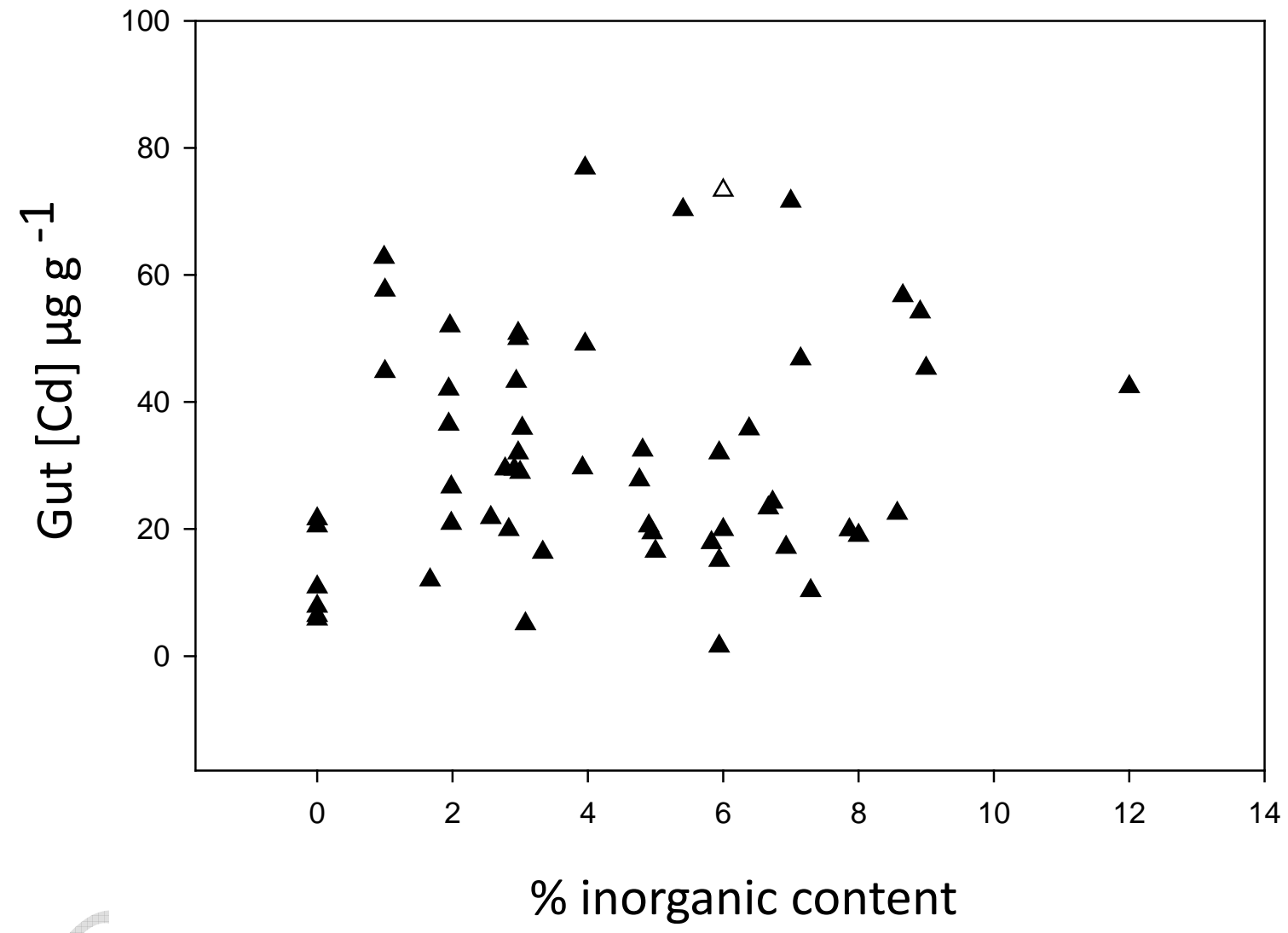

Figure 3 


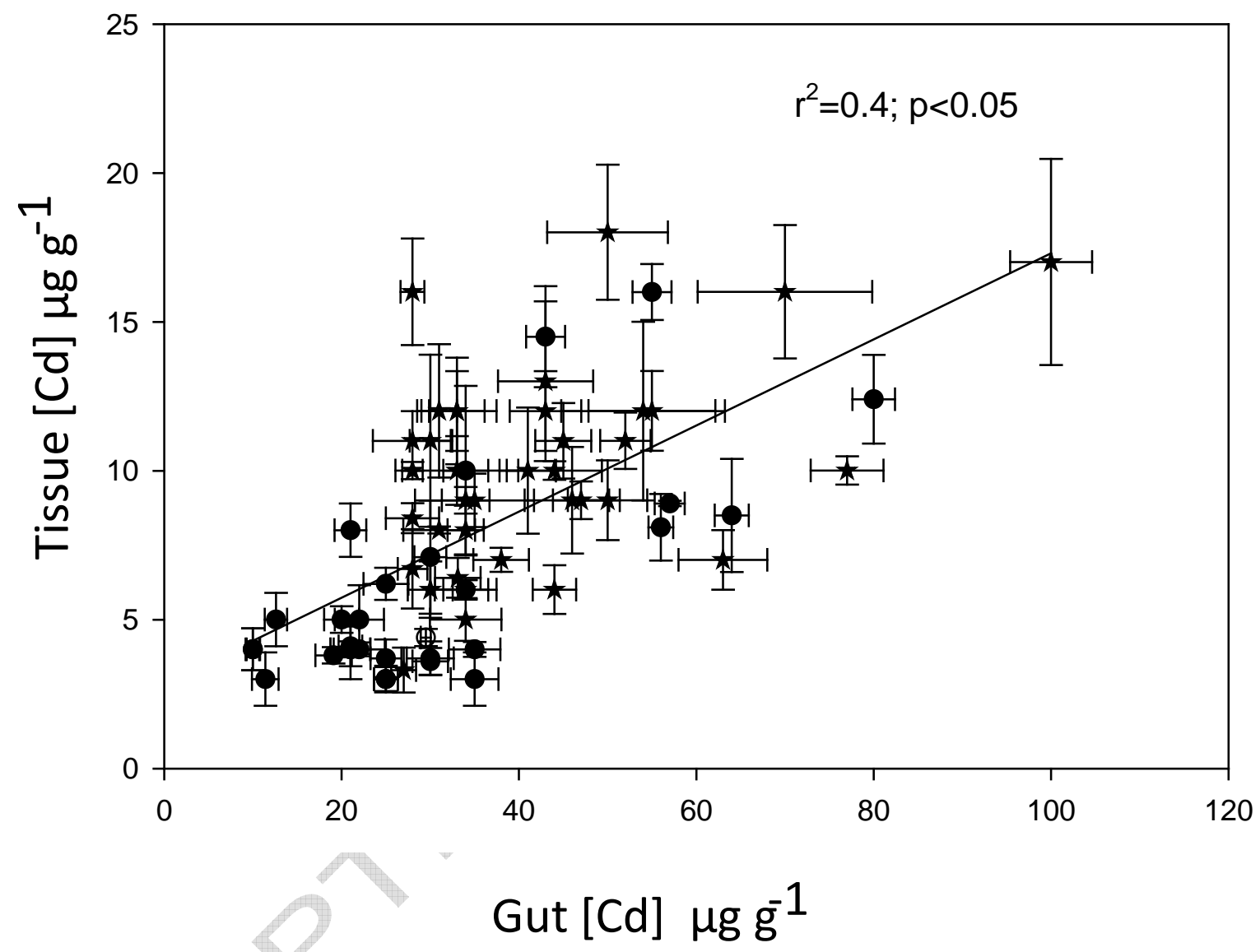

Figure 4 


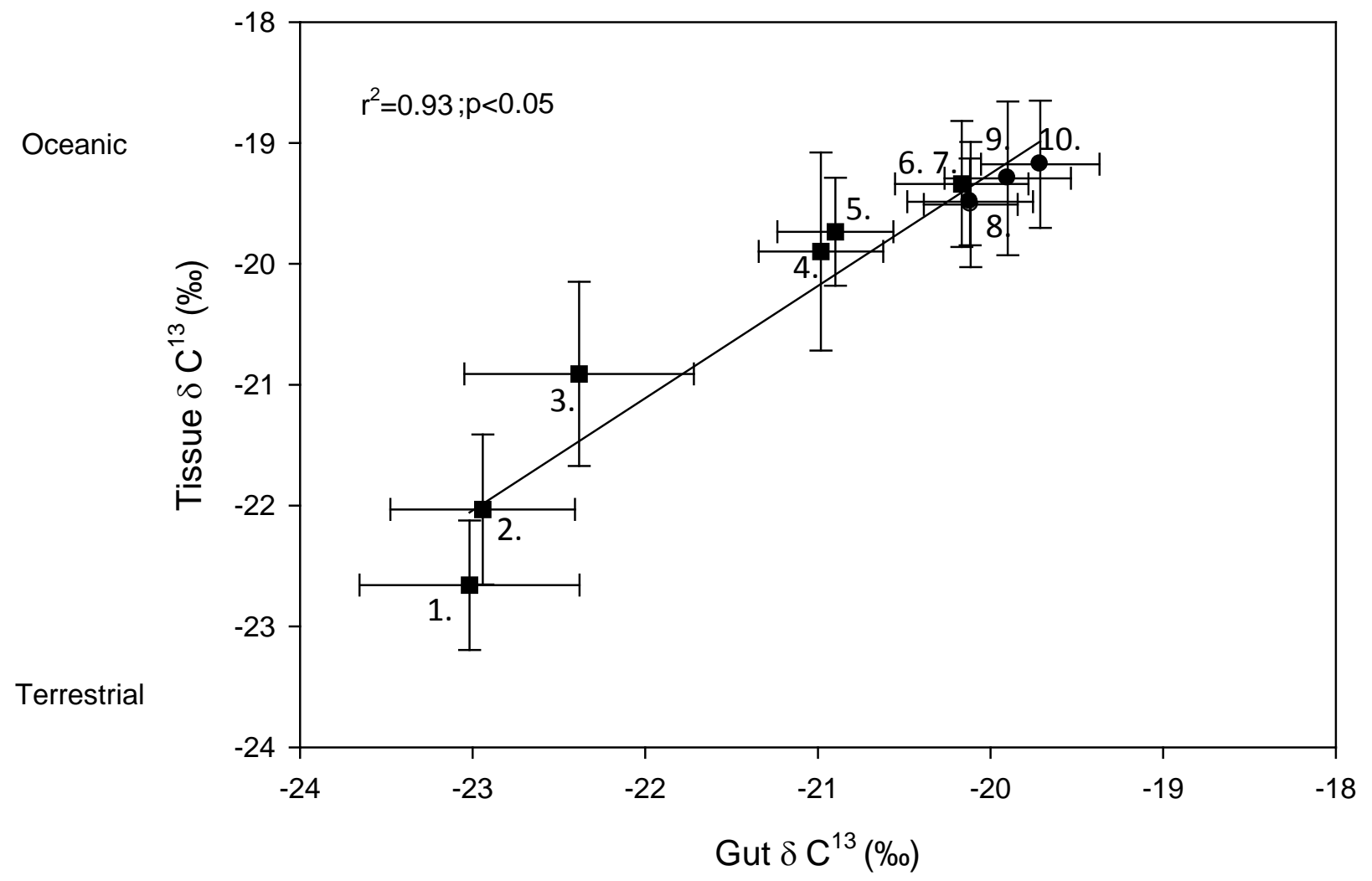

Terrestrial

Oceanic

1. Orchard Bay

2. Teakerne Arm

3. Redonda Bay

4. Trevenen Bay

5. Thor's Cove

6. Gorge Harbor

7. Effingham Inlet

8. Poett Nook

9. Seddall Island

10. Fatty Basin

Figure 7 
Gut

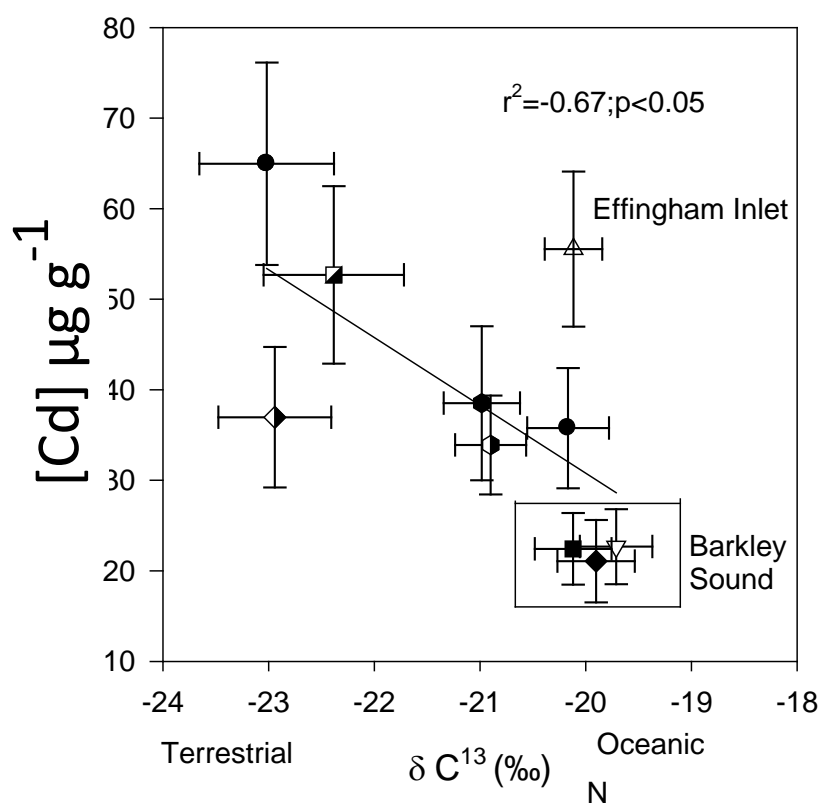

- Effingham Inlet Gut Tissue

$47 \quad 54$

- Gorge Harbor $54 \quad 54$

- Orchard Bay $16 \quad 17$

- Poett Nook $46 \quad 46$

r Redonda Bay $41 \quad 40$

- Seddall Island $44 \quad 44$

\ Teakerne Arm $47 \quad 46$

- Thors Cove $30 \quad 31$

- Trevenen Bay $40 \quad 40$
Tissue

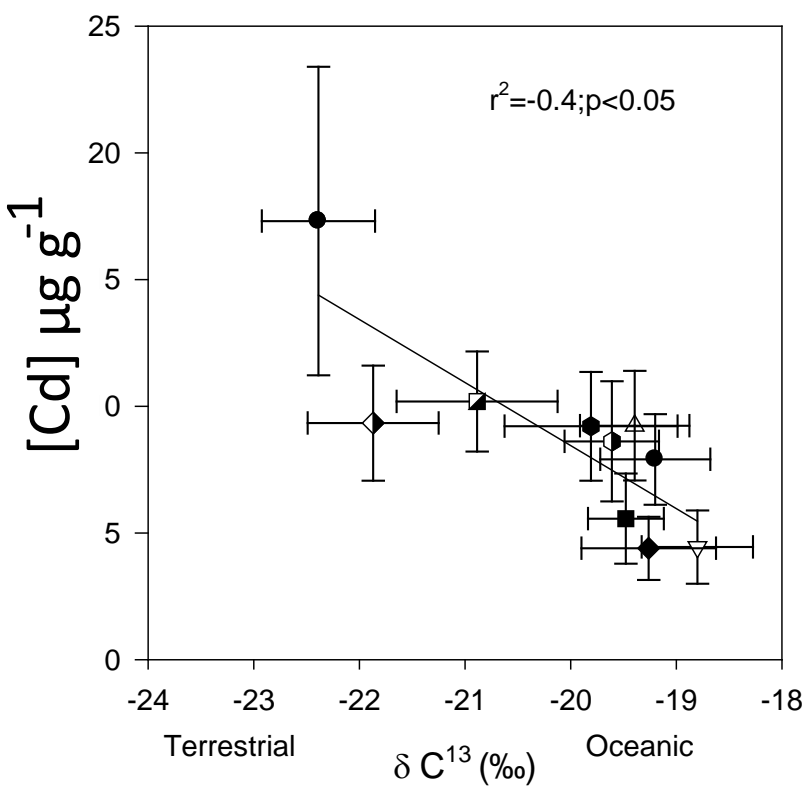

Figure 8 